\section{OPEN ACCESS}

Edited by: Jeff M P Holly,

University of Bristol, United Kingdom

Reviewed by: Antonino Belfiore,

University of Catania, Italy Emily Jane Gallagher, Icahn School of Medicine at Mount Sinai, United States

*Correspondence: Carolyn T. Bramante bramante@umn.edu

Specialty section: This article was submitted to Translational Endocrinology, a section of the journal Frontiers in Endocrinology

Received: 28 July 2020 Accepted: 11 May 2021 Published: 22 July 2021

Citation:

Ibrahim S, Lowe JR, Bramante CT,

Shah S, Klatt NR, Sherwood N, Aronne L, Puskarich M, Tamariz L,

Palacio A, Bomberg E, Usher M,

King S, Benson B, Vojta D, Tignanelli $C$ and Ingraham N (2021) Metformin and Covid-19: Focused Review of Mechanisms and Current

Literature Suggesting Benefit.

Front. Endocrinol. 12:587801. doi: 10.3389/fendo.2021.587801

\title{
Metformin and Covid-19: Focused Review of Mechanisms and Current Literature Suggesting Benefit
}

\begin{abstract}
Sherehan Ibrahim ${ }^{1}$, Jamie R. Lowe ${ }^{2}$, Carolyn T. Bramante ${ }^{1 *}$, Surbhi Shah ${ }^{3}$, Nichole R. Klatt ${ }^{4}$, Nancy Sherwood ${ }^{5}$, Louis Aronne ${ }^{6}$, Michael Puskarich ${ }^{7}$, Leonardo Tamariz ${ }^{8}$, Ana Palacio ${ }^{8}$, Eric Bomberg ${ }^{9}$, Michael Usher ${ }^{1}$, Samantha King ${ }^{1}$, Brad Benson ${ }^{1}$, Deneen Vojta ${ }^{10}$, Chris Tignanelli ${ }^{4}$ and Nicholas Ingraham ${ }^{11}$

${ }^{1}$ Department of Medicine, Division of General Internal Medicine, University of Minnesota, Minneapolis, MN, United States, ${ }^{2}$ MPH Program, Dartmouth College, Hanover, NH, United States, ${ }^{3}$ Department of Medicine, Division of Hematology, Oncology and Transplant, University of Minnesota, Minneapolis, MN, United States, ${ }^{4}$ Department of Surgery, University of Minnesota, Minneapolis, MN, United States, ${ }^{5}$ Department of Epidemiology, University of Minnesota, Minneapolis, MN, United States, ${ }^{6}$ Division of Endocrinology, Cornell Weill College of Medicine, New York, NY, United States, ${ }^{7}$ Department of Emergency Medicine, University of Minnesota, Minneapolis, MN, United States, ${ }^{8}$ Division of Cardiology and Miami VA Healthcare Administration, University of Miami, Miami, FL, United States, ${ }^{9}$ Department of Pediatrics, Division of Pediatric Endocrinology, University of Minnesota, Minneapolis, MN, United States, 10 UnitedHealth Group, Research and Development, Plymouth, MN, United States, ${ }^{11}$ Department of Medicine, Division of Pulmonary, Allergy, Critical Care, and Sleep Medicine, University of Minnesota, Minneapolis, MN, United States
\end{abstract}

Metformin is the first-line medication for type 2 diabetes, but it also has a long history of improved outcomes in infectious diseases, such as influenza, hepatitis C, and in-vitro assays of zika. In the current Covid-19 pandemic, which has rapidly spread throughout the world, 4 observational studies have been published showing reduced mortality among individuals with home metformin use. There are several potential overlapping mechanisms by which metformin may reduce mortality from Covid-19. Metformin's past anti-infectious benefits have been both against the infectious agent directly, as well as by improving the underlying health of the human host. It is unknown if the lower mortality suggested by observational studies in patients infected with Covid-19 who are on home metformin is due to direct activity against the virus itself, improved host substrate, or both.

Keywords: metformin, COVID-19, mechanisms of action, obesity, microbiome

\section{INTRODUCTION}

Metformin was discovered in the 1920s (1). In the 1940s-50s, metformin showed benefit when used in influenza infection, and was noted to lower glucose, but not below physiologic levels (2). Other biguanide medications then had safety issues, so by association metformin then fell out of favor until the 1990s (1). Currently, metformin has Food and Drug Administration (FDA) approval as a firstline medication for type 2 diabetes, on and off-label indications for diabetes prevention in prediabetes; and off label for polycystic ovarian syndrome; anti-psychotic associated weight gain; weight loss; gestational diabetes; and fertility enhancement $(3,4)$. There is also mounting evidence supporting the potential effects of metformin beyond glucose control in the aging population (5). It appears that increased biologic aging may be a key underlying risk factor for poor outcomes from 
severe acute respiratory syndrome coronavirus 2 (SARS-CoV-2) disease, Covid-19, as Covid-19 has disproportionately affected older individuals $(6,7)$.

Several observational cohort studies have been published in peer review journals showing associations with reduced mortality from Covid-19 among patients already who were already on metformin (Table 1) $(8,9,11-13)$. It appears that metformin may be associated with less severe Covid-19 disease, however there are no prospective studies published to date. It must be highlighted that observational results are not conclusive because of the inherent challenge of eliminating residual confounding. Comorbidities associated with Covid-19 outcomes (i.e. hypertension, coronary artery disease, obesity) are commonly present in groups exposed and not exposed to metformin in retrospective cohorts, which make it challenging to know if observational data would be replicated in randomized, prospective trials $(7,28)$.

Here, we present a targeted review of the literature on the mechanistic reasons why metformin might improve outcomes from Covid-19, and a review of the observational data showing the potential benefit from metformin use in Covid-19. Furthermore, given the known sex-specific differences in Covid-19 outcomes (29) and sex-specific associations between metformin and mortality from Covid-19, we also highlight potential sex-specific effects of metformin in this review.

\section{PRIMARY MECHANISM OF ACTIONS}

Currently and prior to the Covid-19 pandemic, the molecular mechanisms by which metformin works have been a topic of debate and responses to metformin have often been variable (30, 31). In patients with diabetes mellitus, metformin improves glycemia largely by decreasing hepatic gluconeogenesis, primarily through phosphorylation of AMP-activated protein kinase (AMPK) (32). Activation of AMPK enhances hepatic insulin sensitivity and gut utilization of glucose, promoting glucagon-like peptide-1 (GLP-1) secretion, and favorably altering the gut microbiome (33). Metformin has been found to have cytokine-reducing effects in both patients with and without diabetes mellitus, which may be of primary import in Covid-19 (34).

The effect of metformin on cytokines has been thought to be mediated by blocking the AMPK cytokine receptor pathway and thus decreasing in proinflammatory genes, though some literature has suggested AMPK-independent means exist as well (34-36).

Cytokine storm leads to severe disease in COVID 19, and hence contributes significantly to morbidity and mortality (37). By the virtue of dampening the cytokine storm, metformin may reduce the morbidity in COVID 19. The many possible mechanisms by which metformin may be protective against Covid-19 have been the topic of several recent papers (38-41). A summary of mechanisms by which metformin has been theorized to convey benefit from Covid-19 is found in Table 2.
We also summarize published literature evaluating the relationship between Covid-19 and metformin use.

\section{THEORIZED MECHANISMS TO SUPPORT THE USE OF METFORMIN IN COVID-19}

\section{High Glucose Is Associated With Worse Covid-19 Outcomes}

Hyperglycemia was found to portend worse outcomes in severe acute respiratory syndrome (SARS) infection in 2003 (72), and is associated with increased length of stay and mortality in patients hospitalized with Covid-19 (58). Worse glucose control has also been associated with higher mortality and end-organ complications in patients with Covid-19 (15). A recent study by Crouse et al. found that metformin use prior to the diagnosis of COVID-19 was associated with a $70 \%$ decrease in mortality in persons with diabetes (10), though this is a larger effect size than what is seen in most studies (10).

\section{Metformin Could Decrease Endothelial Injury and Its Complications}

Metformin has been shown to improve microvascular endothelial function in women, perhaps due to a significant increase in response to acetylcholine, decrease in insulin resistance, and non-significant decrease in tissue plasminogen activating factor, as was shown in a randomized control study of 8 weeks of metformin versus placebo in women with angina and normal coronary arteries (67). Endothelial dysfunction may be an important mechanism and therapeutic target in mitigating Covid-19 sequelae. Metformin decreases thrombosis in longterm follow-up, possibly by inhibiting platelet activation factor and mitochondrial DNA (mtDNA) release $(63,64)$, and may mediate improved cardiovascular outcomes via mechanisms beyond glucose control. COVID associated coagulopathy and thrombosis is a unique attribute of this disease, and the pathophysiology is poorly understood. Widespread micro and macrovascular thrombosis has been reported in autopsies of patients with Covid-19 $(65,66)$.

\section{Metformin Has Been Associated With Beneficial Effects on the Lungs}

In vivo models have demonstrated that metformin overcomes anabolic metabolism promoting AMPK-dependent resolution of lung tissue damage, indicating a potential role in addressing inflammation induced pulmonary fibrosis as a result of severe infections (73). Pulmonary vascular endothelitis has been observed in the lungs of patients with Covid-19 (68). Earlier studies also demonstrated that metformin inhibits AGEsinduced inflammatory response in murine macrophages partly through AMPK activation and RAGE/NF $\kappa \mathrm{B}$ pathway suppression, felt to be important in Covid-19 related lungcentric inflammation and endothelitis (74). Further, metformin has been associated with reduced pulmonary fibrosis through reduced TGF-beta and VEGF, and resolution of pulmonary 
TABLE 1 | Overview of papers in 2020 with findings related to metformin and Covid-19.

\begin{tabular}{|c|c|c|}
\hline Author & Population & Methods \\
\hline \multicolumn{3}{|c|}{ Outcomes in Covid-19 } \\
\hline $\begin{array}{l}\text { Luo et al. (8) } \\
\text { Am J Trop } \\
\text { Med Hyg }\end{array}$ & $\begin{array}{l}283 \text { adults with } \\
\text { T2DM hospitalized } \\
\text { with Covid-19 in } \\
\text { Wuhan. }\end{array}$ & $\begin{array}{l}\text { Retrospective cohort, } 104 \\
\text { adults on metformin with } 179 \\
\text { not on metformin. Metformin } \\
\text { use appears to be home } \\
\text { metformin use. }\end{array}$ \\
\hline $\begin{array}{l}\text { Cariou et al (9), } \\
\text { "Coronado } \\
\text { study" } \\
\text { Diabetalgia }\end{array}$ & $\begin{array}{l}\text { 1,317 adults with } \\
\text { T2DM in France, with } \\
\text { or without home } \\
\text { metformin use }\end{array}$ & $\begin{array}{l}\text { Multi-center observational } \\
\text { study. Main outcome: } \\
\text { mortality or intubation; } \\
\text { Secondary outcome was } \\
\text { mortality }\end{array}$ \\
\hline $\begin{array}{l}\text { Crouse et al. } \\
\text { (10), Frontiers } \\
\text { in } \\
\text { Endocrinology }\end{array}$ & $\begin{array}{l}\text { 25,326 subjects } \\
\text { tested for Covid-19 } \\
\text { between } 2 / 25 / 20 \\
\text { and 6/22/20 in } \\
\text { Alabama. }\end{array}$ & $\begin{array}{l}\text { Retrospective electronic health } \\
\text { records study assessing } \\
\text { mortality in Covid-19 }\end{array}$ \\
\hline $\begin{array}{l}\text { Bramante et al } \\
\text { (11), Lancet } \\
\text { Health and } \\
\text { Longevity }\end{array}$ & $\begin{array}{l}6,256 \text { adults with } \\
\text { T2DM or obesity } \\
\text { hospitalized for } \\
\text { Covid-19 in the US }\end{array}$ & $\begin{array}{l}\text { Retrospective review of USA } \\
\text { UnitedHealth Group claims } \\
\text { data; 2,333 in metformin } \\
\text { group, 3,923 in no-metformin } \\
\text { group }\end{array}$ \\
\hline $\begin{array}{l}\text { Lalau et al (12), } \\
\text { Diabetes \& } \\
\text { Metabolism }\end{array}$ & $\begin{array}{l}2449 \text { adults with } \\
\text { T2DM with or without } \\
\text { previous metformin } \\
\text { use }\end{array}$ & $\begin{array}{l}\text { Multi-center observational } \\
\text { study. Main outcome: } \\
\text { mortality or intubation within } 7 \\
\text { days and } 28 \text { days of } \\
\text { admission }\end{array}$ \\
\hline $\begin{array}{l}\text { Lukito et al } \\
\text { (13), Diabetes } \\
\text { \& Metab Synd: } \\
\text { Clin Res\& Rev }\end{array}$ & $\begin{array}{l}\text { Meta-analysis of } \\
10,233 \text { adults across } \\
9 \text { studies }\end{array}$ & $\begin{array}{l}\text { The mean NOS of the } \\
\text { included studies was } 8.55 \pm \\
0.52 \text {, indicating high-quality } \\
\text { studies. }\end{array}$ \\
\hline
\end{tabular}

Chen et al. (14) 904 patients with Diabetes Care Covid-19, 136 of whom had T2DM

Characteristics and outcomes of patients with T2DM and Covid19. No results reporte for use of GLP-1 receptor agonists.

Zhu et al. (15) 952 adults with

Cell

metabolism T2DM Covid-19 and in Hubei,

China

Montastruc $\quad 10,771$ ICSRs

et al. (16)

Retrospective review. Metformin was given in hospital to 278 patients.

Retrospective review, outcomes of mortality

hydroxychloroquine

Huh et al (18), 65,149 adults, medrxiv.org claims data in S Korea.

Nafakhi et al, 192 patients with Diabetes \& COVID-19 Metab Synd: pneumonia, of Clin Research whom 67 patients \& Reviews had T2DM

Cheng et al. 1,213 patients with Retrospective cohort of (19)

Case control study, metformin $(\mathrm{n}=219)$ vs control $(\mathrm{n}=3604)$

Retrospective cohort of patients with newly diagnosed COVID-19 pneumonia; August 20, to

October 5, 2020 in Iraq individuals hospitalized
- Hospital mortality, metformin vs no metformin: $2.9 \%$ vs $12.3 \%(p=0.01)$

- No difference in length of stay

- No associations with other T2DM meds

- OR for survival: 4.36 (1.22-15.59, $p=0.02$ )

- HbA1C not associated with main outcome $(p=0.28)$ or death $(p=0.91)$

- Preadmission metformin use associated with lower mortality OR 0.59 (0.42, 0.84),

- No association with other T2DM meds

- OR mortality with insulin 1.71 (1.20, 2.43)

Association between prior metformin use and a reduction in mortality $(\mathrm{OR} 0.33,95 \% \mathrm{Cl}$ $0.13-0.84 ; p=0.02$ ) compared to those with T2DM not on metformin.

- Metformin associated with reduced mortality in females: OR $0.759(0.601,0.960)$ by propensity matching; OR $0.780(0.631,0.965)$ by mixed effects; OR $0.785(0.650,0.951)$ by Cox proportionalhazards.

- Mortality rate in metformin users vs non: day 7 (8.2 vs 16.1\%, $P<0.0001)$; day 28 (16.0 vs $28.6 \%, P<0.0001)$

- Mortality by propensity score weighting, metformin users vs non: day 7 OR 0.67 (0.47 -1.01); day 280.71 (0.54-0.94).

- Metformin use associated with lower mortality in pooled non-adjusted model, OR 0.45 (0.25 0.81 ), $\mathrm{p}=0.008$; and adjusted (OR 0.64 (0.43, $0.97), p=0.035$

- Metformin users vs non-users: No significant difference in likelihood of 'poor prognosis': 30\% vs. $50 \%, p=0.688$

- In PCR-confirmed cases, no difference in inhospital death (18.2\% vs $26.1 \%, p=0.77$ ). No associations with DDP-4i's

- Metformin was more likely to be given to those with poor glucose control.

- No metformin specific results reported.

- Hydroxychloroquine + metformin associated with a ROR of 57.7 (23.9-139.3) compared to hydroxychloroquine

- Hydroxychloroquine + metformin was associated with a ROR value of 6.0 (2.6-13.8) compared to metformin alone

- Risk of Infection, crude OR 0.69 (0.60-0.80), aOR: 0.95 (0.81-1.11).

- Metformin use associated with lower ICU days, OR 0.30 (0.20-0.40, $\mathrm{p}=0.03)$; hospital days, OR 0.40 (0.20-0.30,p=0.02); and inhospital mortality OR $0.10(0.1-0.6), p=.025$.

HR Acidosis 2.73 (1.04-7.13, $\mathrm{p}=0.04)$; lactic acidosis $4.46(1.11,18.00, \mathrm{p}=0.04)$
Lower glucose levels in the metformin group, 9.19 vs $7.36(p<0.01)$, no difference in neutrophils or lymphocytes.

CRP 1.99, (1.69, 2.43), lymphocyte count (OR 0.69, 0.60-0.80), fibrinogen OR 1.32 $(1.09,1.58)$ and AST (OR 2.23, 1.70-2.93) predicted mortality.

Glucose levels similar between both groups, Metformin mechanism may reside outside of its glycemia.

In same sample, TNF $\alpha$ inhibitors were associated with decreased mortality (only 38 patients), suggesting TNF $\alpha$ a possible pathway.

Metformin users presented greater case severity on admission regarding clinical, radiological, and biological features, compared with non-users.

SARS-CoV-2 damages $\beta$-cells. Optimal control of T2DM, for chronic and transient cases, may help in treating COVID-19

Metformin users had lower IL-6 (4.07 vs 11.1, $\mathrm{p}=0.02)$. In PCR-confirmed cases, IL-6 was also lower in metformin users than non-metformin users (4.77 vs 11.1, $p=0.024)$.

Worse glucose control associated with mortality and end-organ complications.

More autophagosomes in heart, liver, kidneys of mice treated with both. Synergism of inhibition of mitochondrial complex I, and autophagy from hydroxychloroquine (17).

Covariates: sex, age, region, comorbidities, meds, utilization

Insulin use was associated with extensive lung injury and post-acute COVID-19 pneumonia partial recovery

Appears to be for use of 2-3g/day during hospitalization. 
TABLE 1 | Continued

\begin{tabular}{|c|c|c|}
\hline Author & Population & Mechanism or other findings \\
\hline \multicolumn{3}{|c|}{ Evidence that metformin does reduce TNF-alpha in both males and females. } \\
\hline Author & Population & Finding \\
\hline $\begin{array}{l}\text { Krysiak et al. } \\
\text { (20) }\end{array}$ & $\begin{array}{l}\text { Humans, } 36 \% \text { female, did not compare men vs } \\
\text { women. }\end{array}$ & $\begin{array}{l}\text { After } 12 \text { weeks of treatment, metformin "reduced plasma C-reactive protein levels and } \\
\text { monocyte release of TNF } \alpha \text { and IL-6, as well as tended to reduce monocyte release of IL- } 1 \beta \\
\text { and monocyte chemoattractant protein-1, which was accompanied by an improvement in } \\
\text { insulin sensitivity. }\end{array}$ \\
\hline $\begin{array}{l}\text { Andrews et al. } \\
(21)\end{array}$ & $\begin{array}{l}\text { Humans, men only with obesity and diabetes, ave age } \\
55 \text { years. }\end{array}$ & $\begin{array}{l}\text { Those "treated with metformin had lower levels of hsCRP expression of TNF } \alpha \text { and TLR 2/4, } \\
\text { than their counterparts not receiving the drug." }\end{array}$ \\
\hline Hyun et al. (22) & Mice, male only & Metformin suppresses scavenger receptors in macrophages, down-regulates TNF $\alpha$ \\
\hline \multicolumn{3}{|c|}{ Metformin and sex-specific findings. } \\
\hline Author & Population & Finding \\
\hline $\begin{array}{l}\text { Park, J, et al. } \\
\text { (23) }\end{array}$ & Patients with colorectal cancer & $\begin{array}{l}\text { Interaction test between metformin and sex after adjustment for relevant factors revealed } \\
\text { that female } \mathrm{CRC} \text { patients taking metformin exhibited a significantly lower } \mathrm{CRC} \text {-specific } \\
\text { mortality rate than male } \mathrm{CRC} \text { patients taking metformin }(\mathrm{HR}=0.369,95 \% \mathrm{Cl}: 0.155- \\
0.881, P=0.025) \text {. Subgroup analysis revealed significant differences in } \mathrm{CRC} \text {-specific } \\
\text { mortality between the metformin and non-metformin groups in female patients }(\mathrm{HR}=0.501 \text {, } \\
95 \% \mathrm{Cl} \text { : } 0.286-0.879, P=0.013) \text { but not male patients (HR }=0.848,95 \% \mathrm{Cl} \text { : } 0.594- \\
1.211, P=0.365) \text {. }\end{array}$ \\
\hline DPP (24) & Adults with overweight \& preDM & Metformin reduced CRP by $7 \%$ in men and $14 \%$ in women \\
\hline $\begin{array}{l}\text { Quan, } \mathrm{H} \text {, et al. } \\
\text { (25) }\end{array}$ & 105 human patients & $\begin{array}{l}\text { Combined exenatide and metformin showed better effects on female than male patients for } \\
\text { improving insulin sensitivity and serum lipid profile, reducing insulin resistance, increasing } \\
\text { adiponectin levels, and decreasing the levels of HbA1c, BMl, resistin, TNF-alpha, CRP } \\
(p<0.05) \text {. }\end{array}$ \\
\hline $\begin{array}{l}\text { Naffaa et al } \\
(26) \text {, }\end{array}$ & $\begin{array}{l}\text { 113, } 749 \text { patients who started metformin from 1998- } \\
2014 .\end{array}$ & $\begin{array}{l}\text { Adherence assessed by the mean proportion of follow-up days covered (PDC) with } \\
\text { metformin. Adherence with was associated with a reduced risk of developing RA in women, } \\
\text { not men. }\end{array}$ \\
\hline Jiang et al. (27) & $\begin{array}{l}328 \text { patients with T2D and Covid, } 100 \text { of which were } \\
\text { on metformin while hospitalized }\end{array}$ & $\begin{array}{l}\text { In the mixed-effected model, metformin use was associated with the lower incidence of } \\
\text { ARDS. } \\
\text { Metformin may have potential benefits in reducing the incidence of ARDS in patients with } \\
\text { COVID-19 and type } 2 \text { diabetes. However, this benefit differs significantly by gender as } \\
\text { confirmed by subgroup analysis, metformin use was associated with the lower incidence of } \\
\text { ARDS in females. }\end{array}$ \\
\hline
\end{tabular}

T2DM, Type 2 diabetes mellitus; PCR, Polymerase chain reaction; GLP-1, glucadon-like-peptide 1; DDP-4, Dipeptidyl peptidase-4; WBC, White blood cells, HbA1C, Hemoglobin A1C;

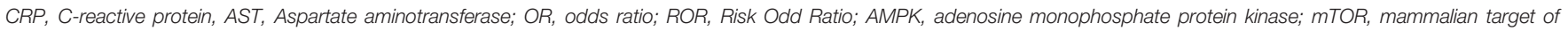

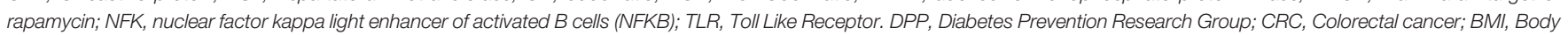
mass index; RA, Rheumatoid arthritis.

fibrosis via activation of lung myofibroblasts $(41,69)$. Pulmonary fibrosis has been noted in persons with Covid-19, specifically in those with elevated IL-6 levels (70).

\section{Metformin Has Immune-Modulatory Effects}

In patients with and without diabetes, metformin has been shown to favorably alter inflammatory mediators, including interleukin 6 (IL-6), TNF $\alpha$, to possibly boost interleukin 10 (IL-10), and suppress the C-C motif chemokine ligand (34, 44-46). Metformin's activation of the AMPK/mTor/Stat3 pathway appears to steer macrophages away from the proinflammatory classical activation that produces TNF/IL6/IL1b, cytokines that contribute to morbidity in Covid-19 $(37,49,50)$. Possible evidence of this effect was seen in a retrospective study by Chen et al: 904 patients with Covid-19 which showed that metformin users had lower IL-6 levels compared to nonmetformin users (Table 2) (56). Metformin also inhibits tolllike-receptor 7 (TLR7) signaling and interferon production, which appears important to Covid-19 pathophysiology (47, 48). Metformin also inhibits IgE- and aryl hydrocarbon- mediated mast cell activation (59). Mast cell activation has been implicated as an early indicator of inflammatory response to SARS-CoV-2. and possibly an indicator of impending cytokine storm $(61,62)$. Mast cells from female rats have been found to cause a greater increase in tumor necrosis factor alpha (TNF-alpha) than mast cells in male rats, which may explain the observational findings of reduced mortality in women on metformin, but not among men on metformin (Table 1) (60).

Metformin decreases neutrophil-extracellular traps (NETs), and the neutrophil to lymphocyte ratio $(34,51,52)$. NETs are microbiocidal compounds containing DNA, histones, and proteins $(51,52)$. Sera from patients with Covid-19 demonstrate elevated levels of these histones and DNA components (52). It has been hypothesized that excessive NET formation leads to cytokine storm and microthrombus (possibly independent of tissue factor), and ultimately acute respiratory distress syndrome (ARDS) in Covid-19 (54). Lymphopenia and neutrophil infiltration in pulmonary capillaries have been an important feature of severe Covid-19 disease (7, 34, 56, 57). Metformin's inhibition of NET release could therefore mitigate the development of downstream lung injury. 
TABLE 2 | Overview of mechanisms of action of metformin and their relationship to SARS-CoV-2 infection.

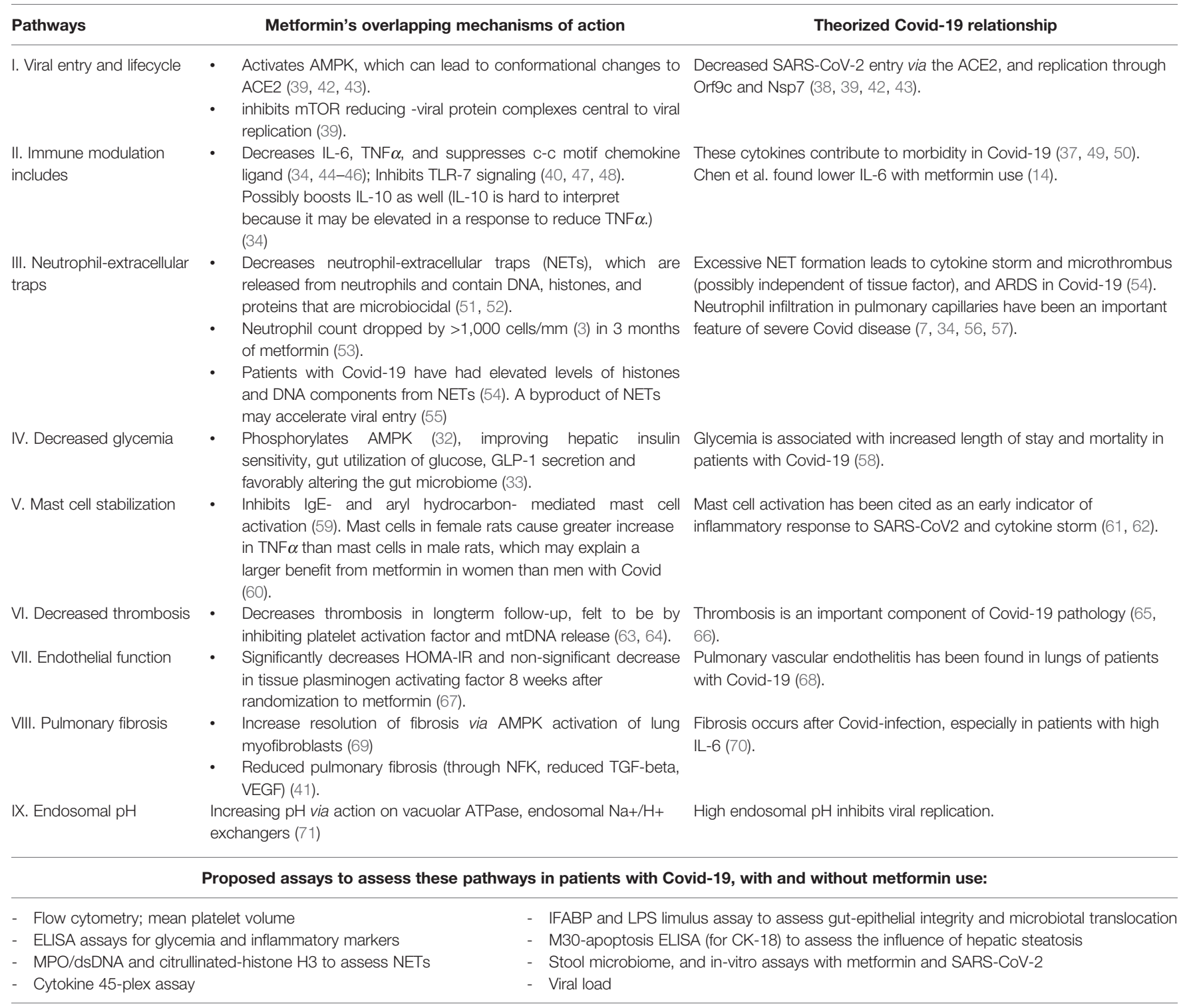

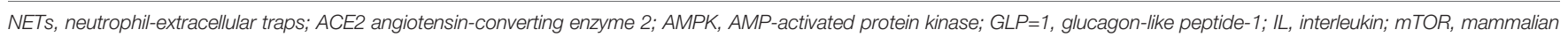
target of rapamycin.

\section{Metformin Could Decrease the Viral Cycle}

There is some evidence that metformin increases endosomal $\mathrm{pH}$ via action on vacuolar ATPase and/or endosomal $\mathrm{Na}+\mathrm{H}+$ exchangers (71), thus reducing viral replication. Metformin also leads indirectly to alteration of the mammalian target of rapamycin (mTOR) pathway (38), which could decrease the viral lifecycle through effects on proteins including Orf9c and Nsp7 (38). Orf9c may enable immune evasion (75), and Nsp7 is necessary for RNA polymerase activity (76). Other studies suggest a link between elevated levels of IL-6 and AMPK/ mTOR signaling pathway and their role in exacerbating diabetes-induced complications and insulin resistance (77). This has led to mTOR inhibitors being suggested as potential therapeutics in treatment of Covid-19 (78). Gordon et al. did find in-vitro efficacy of metformin against SARS-CoV-2, but did not elucidate the mechanism of viral inhibition (79).

\section{Metformin Could Decrease Entry of the SARS-CoV-2 Into Cells}

Activation of AMPK by metformin increases phosphorylation and expression of angiotensin-converting enzyme 2 (ACE2) (80). Phosphorylation of the ACE2 receptor may alter the conformation of the extracellular domain of ACE2 and decrease SARS-Cov-2 entry into cells (6, 39, 42, 43, 81).

$\mathrm{Li}$ and colleagues found that expression of ACE2 is equal in male and female human lungs (82), which differs from one prior study showing lower levels of ACE2 receptor in the lungs of middle-aged male rats, however no sex difference in young and 
old-age rats (83). Li and colleagues did find that the immune response to SARS-CoV-2 in the lungs differs between men and women, with differing cytokine responses (82). This pathologic finding, with our observational findings that metformin conveyed greater protection in women than men, may support that anti-inflammatory effects may be the primary ways in which metformin is protective in Covid-19 (11).

\section{Metformin Also Reduces Body Weight}

Obesity is a known risk factor for poor outcomes in Covid-19 infection, second only to increased age (31). Several studies have shown that metformin use is associated with reduced body weight in patients with and without T2DM $(3,84)$, and growth/differentiating factor 15 (GDF 15) appears to be an important mechanism of action by which metformin causes weight loss (85). An increase in GDF15 has been associated with decreased food intake and lowered body weight (85). It is unknown if weight loss in the weeks, months, or years prior to a Covid-19 infection would improve outcomes from Covid-19.

\section{BY IMPROVING THE MICROBIOME, METFORMIN MAY LIMIT SYSTEMIC INFLAMMATION}

In recent years, it has become increasingly clear that healthy microbial communities that make up the microbiome are critical to human health. Obesity, diabetes mellitus, and other metabolic disorders are all associated with imbalanced microbial communities, known as "microbial dysbiosis." (86) Dysbiosis of the microbiome can result in several deleterious effects that can lead to poor health outcomes, including mucosal and systemic inflammation, microbial translocation, and damage to the tight epithelial barrier of mucosal sites such as the gut. Furthermore, novel studies have demonstrated that Covid-19 disease is associated with microbial dysbiosis, which may be a potential mechanism underlying overt inflammation and dysregulated immunity in Covid-19 disease $(87,88)$.

Given the above, another mechanism by which metformin may limit disease severity in Covid-19 is by enhancing the microbiome to promote anti-inflammatory effects. Indeed, several studies have demonstrated that metformin can alter the microbiome in a potentially beneficial manner. This includes: (i.) increased "probiotic" strains (i.e. beneficial, anti-inflammatory bacteria such as Lactobacillus) (89). (ii.) increased bacteria strains such as Bifidobacteria, Megasphera, Ruminococcus, and Butyrivibrio that produce short-chain fatty acids $(89,90)$ which are essential for epithelial barrier function and regulation of inflammation; (iii.) increased bacteria strains such as Bacteroides spp. that produce bile acids, which are essential in cholesterol homeostasis and metabolic health (91); (iv.) improvement of microbial communities associated with decreased overall inflammation through lowered TLR-4 signaling, microbial translocation and barrier dysfunction (86, 89); (v.) increased levels of bacteria such as Akkermansia species that degrade mucins, which can prevent biofilms from forming that can promote inflammatory bacteria species; and (vi.) reduced bacteria known to be associated with barrier damage and inflammation including Prevotella. While there are some conflicting reports regarding microbial alterations after metformin treatment (92), this is likely due to confounders and study design. Overall, it appears that metformin improves the microbiome and can contribute to better mucosal health and overall lowered inflammation. Thus, a potential mechanism by which metformin may improve prognosis in Covid-19 may be through improvement of the microbiome and downstream lowered inflammation.

\section{METFORMIN AND SEX-SPECIFIC INFLAMMATORY AND MORTALITY FINDINGS}

As mentioned, observational data suggest a mortality benefit only among female adult patients with diabetes or obesity hospitalized with Covid-19 (Table 1) (11). Another study found reduced incidence of ARDS in patients with Covid-19 taking metformin $v s$ those who were not; however, this association was only found among females (27). Additionally, metformin use has been associated with a sex-specific mortality benefit in women compared to men with colorectal cancer (23). Possible reasons for sex-specific effects of metformin include the influence of sex hormones and epigenetic changes on the Y chromosome (93). While metformin has been associated with decreased TNF-alpha use after starting metformin in both men and women, these benefits have been shown to be greater in females versus males in several studies (see Table 1) $(23,25,34$, 94, 95). These sex-specific findings may be related to c-src modulation of sex steroids (96).

The National Institutes of Health started to seriously promote sex as a biologic variable in 2014 (97). Much of the mechanistic research into the basic science behind metformin was done before 2014, which may limit the understanding of sex-specific effects of metformin. This remains an important area for future investigation (98).

\section{METFORMIN'S HISTORY OF ANTI- INFECTIOUS PROPERTIES}

Metformin was found to have antiviral activity before SARSCoV-2. In the 1940s and 1950s, metformin was used against influenza (as "Flumamine"), and was found to be effective against parainfluenza and cowpox $(1,99)$. Metformin has also been associated with improved affect against tuberculosis and is being assessed in HIV (100). With the Zika virus, another RNA virus, activation of AMPK by metformin resulted in restricted viral replication by potentiating innate antiviral responses and decreasing glycolysis, with PKA Inhibitor PKI leading to decreased viral infection and replication $(101,102)$. Metformin was only assessed in-vitro against Zika, not in-vivo. In patients 
with hepatitis $\mathrm{C}$, metformin has been associated with improved virologic response to antivirals and decreased insulin resistance (103). Metformin's past anti-infectious benefits have been both against the infectious agent directly, as well as by improving the underlying health of the human host. In May 2020, Gordon et al. did find that metformin both reduced SARS-CoV-2 virus and improved cell viability during in-vitro assays (79). It is unknown if the lower mortality observed in patients infected with Covid-19 who are on metformin is due to direct activity against the virus itself, improved host substrate (i.e. lower inflammation preinfection, or lower biologic aging), or both.

\section{SAFETY}

Metformin is overall a safe medication that has been widely used for decades (104). It is well-tolerated in most individuals, and there is flexibility in the timing of administration which can improve side-effects and adherence (105). Metformin use without other glucose-lowering medications does not lead to glucose reduction below physiologic levels. For this reason, it is considered a safe medication among older adults (106). The most common safety concern is the possibility of lactic acidosis, but this adverse side effect is rare (104) A review found that, even in patients with advanced liver disease, the risk for lactic acidosis is low (107). Recent evidence from Cheng et al. also found that, inpatient metformin use of 2 to $3 \mathrm{~g} /$ day was significantly associated with an increased incidence of developing lactic acidosis (OR, 22.57; 95\% CI, 1.99-256.71; $\mathrm{p}=0.012$ ) and acidosis (OR, 12.79; 95\% CI, $1.24-132.14 ; \mathrm{p}=0.032)$, neither low-dose $(<1 \mathrm{~g} /$ day $)$ nor moderate-dose ( 1 to $2 \mathrm{~g} /$ day) was significantly associated with the acidosis or lactic acidosis. Additionally, the incidence of heart failure was significantly lower in the metformin group compared to the non-metformin group (adjusted HR, 0.61; 95\% CI, 0.43$0.87 ; \mathrm{p}=0.006)(19)$. An analysis of individual case safety reports of persons with Covid-19 on hydroxychloroquine suggested an increased risk of mortality associated with hydroxychloroquine + metformin use (ROR value of 57.7 (23.9-139.3) compared to hydroxychloroquine use alone (16). The authors found autophagosomes in mice treated with both, and hypothesized that the excess mortality was from a synergistic inhibition of autophagy (16). Caution should be considered for co-administration in humans.

There is currently a voluntary FDA recall of some long-acting metformin. While some manufacturers of long-acting metformin are currently under voluntary recall because of elevated nitrosodimethylamine (NDMA), a water treatment chemical, no elevated levels of NDMA have been found in the short acting formulation (108).

Additionally, while metformin does cross the placenta, it appears to be safe and has been used off-label in pregnancy. In studies randomizing pregnant women to glucose-lowering therapy, metformin was associated with lower gestational weight gain and a lower risk of pre-eclampsia compared with insulin. Further, other randomized controlled trials have found that metformin is associated with reduced risk of hypertensive disorders of pregnancy in women with obesity or diabetes mellitus (109, 110). Most medications being considered for Covid-19 treatment and prevention are safe during pregnancy.

\section{CONCLUSION}

The goal of this targeted review was to provide a high-level overview of initial data around metformin and Covid-19, and mechanistic theories and data that pre-dated Covid-19. Observational studies have suggested associations with decreased risk of mortality in patients who were on metformin before being hospitalized with Covid-19. Observational studies are significantly limited by confounding by indication and contraindication. While many laboratory studies suggest plausible mechanistic reasons why metformin would be protective in Covid-19, and metformin has been shown to inhibit SARS-CoV-2 in vitro, the data so far are not conclusive. Given the above-mentioned observational findings, plausible mechanisms of metformin's effect in reducing Covid-19 related morbidity/mortality, acceptable safety profile, low cost, and the devastating nature of the global Covid-19 pandemic, metformin should be prospectively assessed as a potential Covid-19 treatment. Additionally, observational studies should assess outcomes in individuals who are chronically on hydroxychloroquine and metformin, as there may be a safety issue in this combination.

While vaccine development for SARS-CoV-2 has been promising and is the most important approach to preventing severe COVID-19, there may be reduced willingness among the public to receive a vaccine developed so quickly. Additionally, it will be many months before vaccines are available world-wide, some individuals will still get Covid-19 even after vaccination, and at times viral variants may evade vaccine effectiveness until new vaccines can be distributed (111). Because medical practice should not change without being informed by rigorous data, randomized clinical trials should be done to prospectively assess safe and readily available medications such as metformin for reducing the risks associated to Covid-19.

\section{AUTHOR CONTRIBUTIONS}

SI contributed to the planning and execution of the significant revisions. JL contributed to the updating of the manuscript and content. CB wrote the initial draft of the manuscript. NI contributed to critical review and making the figure. SS contributed to critical review and making the figure. NK wrote parts of the article and contributed to critical review. NS contributed to critical review. LA contributed to critical review. MP contributed to critical review and designing the article. LT contributed to critical review and making the figure. AP contributed to critical review. EB contributed to critical review. MU contributed to critical review and making the figure; $\mathrm{BB}$ contributed to critical review. DV contributed to critical review. CT contributed to critical review and conceptualizing the manuscript. All authors contributed to the article and approved the submitted version. 


\section{FUNDING}

1. This research was supported by the Agency for Healthcare Research and Quality (AHRQ) and Patient-Centered Outcomes Research Institute (PCORI), grant K12HS026379 (CJT).

2. This research was supposed by the Minnesota Learning Health System Mentored Training Program (MH-LHS), M Health Fairview Institutional Funds (CTB, SS).

\section{REFERENCES}

1. Bailey CJ. Metformin: Historical Overview. Diabetologia (2017) 60(9):156676. doi: 10.1007/s00125-017-4318-z

2. G U, L F, SL S. Pharmacological Studies of a New Oral Hypoglycemic Drug. Proc Soc Exp Biol Med (1957) 95:190-2. doi: 10.3181/00379727-9523163

3. Igel LI, Sinha A, Saunders KH, Apovian CM, Vojta D, Aronne LJ. Metformin: An Old Therapy That Deserves a New Indication for the Treatment of Obesity. Curr Atheroscler Rep (2016) 18(4):16. doi: 10.1007/ s11883-016-0568-3

4. Desilets AR, Dhakal-Karki S, Dunican KC. Role of Metformin for Weight Management in Patients Without Type 2 Diabetes. Ann Pharmacother (2008) 42(6):817-26. doi: 10.1345/aph.1K656

5. Valencia WM, Palacio A, Tamariz L, Florez H. Metformin and Ageing: Improving Ageing Outcomes Beyond Glycaemic Control. Diabetologia (2017) 60(9):1630-8. doi: 10.1007/s00125-017-4349-5

6. Kuo CL, Pilling LC, Atkins JC, Masoli J, Delgado J, Tignanelli C, et al. Biological Aging Predicts Vulnerability to COVID-19 Severity in UK Biobank Participants. J Gerontol A Biol Sci Med Sci (2021) glab060. doi: 10.1093/gerona/glab060

7. Richardson S, Hirsch JS, Narasimhan M, Crawford JM, McGinn T, Davidson KW, et al. Presenting Characteristics, Comorbidities, and Outcomes Among 5700 Patients Hospitalized With Covid-19 in the New York City Area. JAMA (2020) 323(20):2052-9. doi: 10.1001/jama.2020.6775

8. Luo P, Qiu L, Liu Y, Liu XL, Zheng JL, Xue HY, et al. Metformin Treatment was Associated With Decreased Mortality in COVID-19 Patients With Diabetes in a Retrospective Analysis. Am J Trop Med Hyg (2020) 103(1):6972. doi: 10.4269/ajtmh.20-0375

9. Cariou B, Hadjadj S, Wargny M, Pichelin M, Al-Salameh A, Allix I, et al. Phenotypic Characteristics and Prognosis of Inpatients With COVID-19 and Diabetes: The CORONADO Study. Diabetologia (2020) 63(8):1500-15. doi: $10.1007 / \mathrm{s} 00125-020-05180-\mathrm{x}$

10. Crouse AB, Grimes T, Li P, Might M, Ovalle F, Shalev A. Metformin Use is Associated With Reduced Mortality in a Diverse Population With Covid-19 and Diabetes. Front Endocrinol (2021) 1081:11. doi: 10.3389/fendo. 2020.600439

11. Bramante CT, Ingraham NE, Murray TA, Marmor S, Hovertsen S, Gronski J, et al. Metformin and Risk of Mortality in Patients Hospitalised With COVID-19: A Retrospective Cohort Analysis. Lancet Healthy Long (2021) 2(1):e34-41. doi: 10.1016/S2666-7568(20)30033-7

12. Lalau J-D, Al-Salameh A, Hadjadj S, Goronflot T, Wiernsperger N, Pichelin M, et al. Metformin Use is Associated With a Reduced Risk of Mortality in Patients With Diabetes Hospitalised for COVID-19. Diabetes Metab (2020) 2020:101216. doi: 10.1016/j.diabet.2020.101216

13. Lukito AA, Pranata R, Henrina J, Lim MA, Lawrensia S, Suastika K. The Effect of Metformin Consumption on Mortality in Hospitalized Covid-19 Patients: A Systematic Review and Meta-Analysis. Diabetes Metab Syndrome (2020) 14(6):2177-83. doi: 10.1016/j.dsx.2020.11.006

14. Chen Y, Yang D, Cheng B, Chen J, Peng A, Yang C, et al. Clinical Characteristics and Outcomes of Patients With Diabetes and COVID-19 in Association With Glucose-Lowering Medication. Diabetes Care (2020) 43 (7):1399-407. doi: 10.2337/dc20-0660

15. Zhu L, She ZG, Cheng X, Qin JJ, Zhang XJ, Cai J, et al. Association of Blood Glucose Control and Outcomes in Patients With COVID-19 and
3. This research was supported by the National Center for Advancing Translational Sciences, grants KL2TR002492 and UL1TR002494 (CTB).

4. This research was supported by the National Heart, Lung, Blood Institute T32HL07741 (NEI).

5. This research was supported by the National Cancer Institute (NCI), grant P30CA077598.

6. This research was supported by COVID-19 Rapid response grant UM 2020-2231.

Pre-existing Type 2 Diabetes. Cell Metab (2020) 31(6):1068-1077 e1063. doi: 10.1016/j.cmet.2020.04.021

16. Montastruc JL, Toutain PL. A New Drug-Drug Interaction Between Hydroxychloroquine and Metformin? A Signal Detection Study. Drug Saf (2020) 43(7):657-60. doi: 10.1007/s40264-020-00955-y

17. Rajeshkumar NV, Yabuuchi S, Pai SG, Maitra A, Hidalgo M, Dang CV. Fatal Toxicity of Chloroquine or Hydroxychloroquine With Metformin in Mice. bioRxiv (2020). 2020.2003.2031.018556. doi: 10.1101/2020.03.31.018556

18. Huh K, Ji W, Kang M, Hong J, Bae GH, Lee R, et al. Association of Previous Medications With the Risk of COVID-19: A Nationwide Claims-Based Study From South Korea. MedRxiv (2020). doi: 10.1101/2020.05.04.20089904

19. Cheng X, Liu YM, Li H, Zhang X, Lei F, Qin JJ, et al. Metformin Is Associated With Higher Incidence of Acidosis, But Not Mortality, in Individuals With COVID-19 and Pre-existing Type 2 Diabetes. Cell Metab (2020) 32(4):537-547 e533. doi: 10.1016/j.cmet.2020.08.013

20. Krysiak R, Gdula-Dymek A, Okopien B. Monocyte-Suppressing Effect of High-Dose Metformin in Fenofibrate-Treated Patients With Impaired Glucose Tolerance. Pharmacol Rep (2013) 65(5):1311-6. doi: 10.1016/ S1734-1140(13)71489-0

21. Andrews M, Soto N, Arredondo M. Efecto De Metformina Sobre La Expresi $\sqrt{ } \geq \mathrm{N}$ Del Factor De Necrosis Tumoral- \pm , Los Receptores Toll-like 2/ 4 Y La PCR Ultra Sensible En Sujetos Obesos Con Diabetes Tipo 2. Rev $m \sqrt{ }$ (dica Chile (2012) 140:1377-82. doi: 10.4067/S0034-98872012001100001

22. Hyun B, Shin S, Lee A, Lee S, Song Y, Ha NJ, et al. Metformin Downregulates TNF-Alpha Secretion Via Suppression of Scavenger Receptors in Macrophages. Immune Netw (2013) 13(4):123-32. doi: 10.4110/in.2013. 13.4.123

23. Park JW, Lee JH, Park YH, Park SJ, Cheon JH, Kim WH, et al. SexDependent Difference in the Effect of Metformin on Colorectal CancerSpecific Mortality of Diabetic Colorectal Cancer Patients. World J Gastroenterol (2017) 23(28):5196-205. doi: 10.3748/wjg.v23.i28.5196

24. Diabetes Prevention Program Research G. Lipid, Lipoproteins, C-reactive Protein, and Hemostatic Factors at Baseline in the Diabetes Prevention Program. Diabetes Care (2005) 28(10):2472-9. doi: 10.2337/diacare. 28.10.2472

25. Quan H, Zhang H, Wei W, Fang T. Gender-Related Different Effects of a Combined Therapy of Exenatide and Metformin on Overweight or Obesity Patients With Type 2 Diabetes Mellitus. J Diabetes Complicat (2016) 30 (4):686-92. doi: 10.1016/j.jdiacomp.2016.01.013

26. Naffaa ME, Rosenberg V, Watad A, Tiosano S, Yavne Y, Chodick G, et al. Adherence to Metformin and the Onset of Rheumatoid Arthritis: A Population-Based Cohort Study. Scand J Rheumatol (2020) 49(3):173-80. doi: 10.1080/03009742.2019.1695928

27. Jiang N, Chen Z, Yin X, Liu L, Yang H, Tan X, et al. Association of Metformin With Mortality or ARDS in Patients With COVID-19 and Type 2 Diabetes: A Retrospective Cohort Study. Diabetes Res Clin Pract (2020) 173:108619. doi: 10.1016/j.diabres.2020.108619

28. Simonnet A, Chetboun M, Poissy J, Raverdy V, Noulette J, Duhamel A, et al High Prevalence of Obesity in Severe Acute Respiratory Syndrome Coronavirus-2 (SARS-Cov-2) Requiring Invasive Mechanical Ventilation. Obes (Silver Spring Md) (2020) 28(7):1195-9. doi: 10.1002/oby.22831

29. Ingraham NE, Barakat AG, Reilkoff R, Bezdicek T, Schacker T, Chipman JG, et al. Understanding the renin-angiotensin-aldosterone-SARS-CoV Axis: A Comprehensive Review. Eur Respir J (2020) 56(1):2000912. doi: 10.1183/ 13993003.00912-2020 
30. Gong L, Goswami S, Giacomini KM, Altman RB, Klein TE. Metformin Pathways: Pharmacokinetics and Pharmacodynamics. Pharmacogenet Genomics (2012) 22(11):820-7. doi: 10.1097/FPC.0b013e3283559b22

31. Graham GG, Punt J, Arora M, Day RO, Doogue MP, Duong JK, et al. Clinical Pharmacokinetics of Metformin. Clin Pharmacokinet (2011) 50 (2):81-98. doi: 10.2165/11534750-000000000-00000

32. Zhou G, Myers R, Li Y, Chen Y, Shen X, Fenyk-Melody J, et al. Role of AMPactivated Protein Kinase in Mechanism of Metformin Action. J Clin Invest (2001) 108(8):1167-74. doi: 10.1172/JCI13505

33. Rena G, Hardie DG, Pearson ER. The Mechanisms of Action of Metformin. Diabetologia (2017) 60(9):1577-85. doi: 10.1007/s00125-017-4342-Z

34. Cameron AR, Morrison VL, Levin D, Mohan M, Forteath C, Beall C, et al. Anti-Inflammatory Effects of Metformin Irrespective of Diabetes Status. Circ Res (2016) 119(5):652-65. doi: 10.1161/CIRCRESAHA.116.308445

35. Saisho Y. Metformin and Inflammation: Its Potential Beyond Glucoselowering Effect. Endocr Metab Immune Disord Drug Targets (2015) 15 (3):196-205. doi: 10.2174/1871530315666150316124019

36. Mancini SJ, White AD, Bijland S, Rutherford C, Graham D, Richter EA, et al. Activation of AMP-Activated Protein Kinase Rapidly Suppresses Multiple Pro-Inflammatory Pathways in Adipocytes Including IL-1 ReceptorAssociated Kinase-4 Phosphorylation. Mol Cell Endocrinol (2017) 440:4456. doi: 10.1016/j.mce.2016.11.010

37. Ingraham NE, Lotfi-Emran S, Thielen BK, Techar K, Morris RS, Holtan SG, et al. Immunomodulation in COVID-19. Lancet Respir Med (2020) 8 (6):544-6. doi: 10.1016/S2213-2600(20)30226-5

38. Gordon DE, Jang GM, Bouhaddou M, Xu J, Obernier K, O’Meara MJ, et al. A SARS-CoV-2-Human Protein-Protein Interaction Map Reveals Drug Targets and Potential Drug-Repurposing. bioRxiv (2020) 583:459-68. doi: 10.1038/s41586-020-2286-9

39. Sharma S, Ray A, Sadasivam B. Metformin in COVID-19: A Possible Role Beyond Diabetes. Diabetes Res Clin Pract (2020) 164:108183. doi: 10.1016/ j.diabres.2020.108183

40. Singh AK, Singh R. Is Metformin Ahead in the Race as a Repurposed HostDirected Therapy for Patients With Diabetes and COVID-19? Diabetes Res Clin Pract (2020) 165:108268. doi: 10.1016/j.diabres.2020.108268

41. Esam Z. A Proposed Mechanism for the Possible Therapeutic Potential of Metformin in COVID-19. Diabetes Res Clin Pract (2020) 167:108282. doi: 10.1016/j.diabres.2020.108282

42. Liu J, Li X, Lu Q, Ren D, Sun X, Rousselle T, et al. AMPK: A Balancer of the Renin-Angiotensin System. Biosci Rep (2019) 39(9). doi: 10.1042/ BSR20181994

43. Plattner F, Bibb JA. Serine and Threonine Phosphorylation. In: ST Brady, GJ Siegel, RW Albers, DL Price, editors. Basic Neurochemistry. New York: Academic Press (2012). p. 467-92.

44. Ursini F, Russo E, Pellino G, D’Angelo S, Chiaravalloti A, De Sarro G, et al. Metformin and Autoimmunity: A "New Deal" of an Old Drug. Front Immunol (2018) 9(1236):1236. doi: 10.3389/fimmu.2018.01236

45. Dehkordi AH, Abbaszadeh A, Mir S, Hasanvand A. Metformin and its AntiInflammatory and Anti-Oxidative Effects; New Concepts. J Renal Injury Prev (2018) 8(1):54-61. doi: 10.15171/jrip.2019.11

46. Afshari K, Dehdashtian A, Haddadi NS, Haj-Mirzaian A, Iranmehr A, Ebrahimi MA, et al. Anti-Inflammatory Effects of Metformin Improve the Neuropathic Pain and Locomotor Activity in Spinal Cord Injured Rats: Introduction of an Alternative Therapy. Spinal Cord (2018) 56(11):1032-41. doi: 10.1038/s41393-018-0168-x

47. Saenwongsa W, Nithichanon A, Chittaganpitch M, Buayai K, Kewcharoenwong C, Thumrongwilainet B, et al. Metformin-Induced Suppression of IFN-alpha Via mTORC1 Signalling Following Seasonal Vaccination is Associated With Impaired Antibody Responses in Type 2 Diabetes. Sci Rep (2020) 10(1):3229. doi: 10.1038/s41598-020-60213-0

48. van der Made CI, Simons A, Schuurs-Hoeijmakers J, van den Heuvel G, Mantere T, Kersten S, et al. Presence of Genetic Variants Among Young Men With Severe Covid-19. JAMA (2020). doi: 10.1001/jama.2020.13719

49. Mehta P, McAuley DF, Brown M, Sanchez E, Tattersall RS, Manson JJ, et al. Covid-19: Consider Cytokine Storm Syndromes and Immunosuppression. Lancet (2020) 395(10229):1033-4. doi: 10.1016/S0140-6736(20)30628-0

50. Berlin DA, Gulick RM, Martinez FJ. Severe Covid-19. New Engl J Med (2020). doi: 10.1056/NEJMcp2009575
51. Bendib I, de Chaisemartin L, Granger V, Schlemmer F, Maitre B, Hue S, et al. Neutrophil Extracellular Traps Are Elevated in Patients With Pneumoniarelated Acute Respiratory Distress Syndrome. Anesthesiology (2019) 130 (4):581-91. doi: 10.1097/ALN.0000000000002619

52. Zuo Y, Yalavarthi S, Shi H, Gockman K, Zuo M, Madison JA, et al. Neutrophil Extracellular Traps in COVID-19. JCI Insight (2020) 5(11). doi: 10.1101/2020.04.30.20086736

53. Ibanez L, Jaramillo AM, Ferrer A, de Zegher F. High Neutrophil Count in Girls and Women With Hyperinsulinaemic Hyperandrogenism: Normalization With Metformin and Flutamide Overcomes the Aggravation by Oral Contraception. Hum Reprod (2005) 20(9):2457-62. doi: 10.1093/humrep/dei072

54. Almeida VH, Rondon AMR, Gomes T, Monteiro RQ. Novel Aspects of Extracellular Vesicles as Mediators of Cancer-Associated Thrombosis. Cells (2019) 8(7). doi: 10.3390/cells8070716. Accessed 2019/07//.

55. Thierry AR, Roch B. Neutrophil Extracellular Traps and by-Products Play a Key Role in COVID-19: Pathogenesis, Risk Factors, and Therapy. J Clin Med (2020) 9(9):2942. doi: 10.3390/jcm9092942

56. Chen R, Sang L, Jiang M, Yang Z, Jia N, Fu W, et al. Longitudinal Hematologic and Immunologic Variations Associated With the Progression of COVID-19 Patients in China. J Allergy Clin Immunol (2020) 146(1):89-100. doi: 10.1016/j.jaci.2020.05.003

57. Zeng F, Li L, Zeng J, Deng Y, Huang H, Chen B, et al. Can We Predict the Severity of Coronavirus Disease 2019 With a Routine Blood Test? Pol Arch Intern Med (2020) 130(5):400-6. doi: 10.20452/pamw.15331

58. Bode B, Garrett V, Messler J, McFarland R, Crowe J, Booth R, et al. Glycemic Characteristics and Clinical Outcomes of COVID-19 Patients Hospitalized in the United States. J Diabetes Sci Technol (2020) 14(4):813-21. doi: 10.1177/1932296820924469

59. Wang HC, Huang SK. Metformin Inhibits IgE- and Aryl Hydrocarbon Receptor-Mediated Mast Cell Activation In Vitro and In Vivo. Eur J Immunol (2018) 48(12):1989-96. doi: 10.1002/eji.201847706

60. Mackey E, Ayyadurai S, Pohl CS, DC S, Li Y, Moeser AJ. Sexual Dimorphism in the Mast Cell Transcriptome and the Pathophysiological Responses to Immunological and Psychological Stress. Biol Sex Differ (2016) 7:60. doi: 10.1186/s13293-016-0113-7

61. Kritas SK, Ronconi G, Caraffa A, Gallenga CE, Ross R, Conti P. Mast Cells Contribute to Coronavirus-Induced Inflammation: New Anti-Inflammatory Strategy. J Biol Regul Homeost Agents (2020) 34(1):9-14. doi: 10.23812/20Editorial-Kritas

62. Theoharides TC. Covid-19, Pulmonary Mast Cells, Cytokine Storms, and Beneficial Actions of Luteolin. Biofactors (2020) 46(3):306-8. doi: 10.1002/ biof. 1633

63. Xin G, Wei Z, Ji C, Zheng H, Gu J, Ma L, et al. Metformin Uniquely Prevents Thrombosis by Inhibiting Platelet Activation and mtDNA Release. Sci Rep (2016) 6:36222. doi: 10.1038/srep36222

64. Lu D-Y, Leu H-B. Metformin and Risk of Deep Vein Thrombosis: A Nonrandomized, Pair-Matched Cohort Study. J Am Coll Cardiol (2014) 63 (12):A2099. doi: 10.1016/S0735-1097(14)62102-1

65. Levi M, Thachil J, Iba T, Levy JH. Coagulation Abnormalities and Thrombosis in Patients With COVID-19. Lancet Haematol (2020) 7(6): e438-40. doi: 10.1016/S2352-3026(20)30145-9

66. Bikdeli B, Madhavan MV, Jimenez D, Chuich T, Dreyfus I, Driggin E, et al. Covid-19 and Thrombotic or Thromboembolic Disease: Implications for Prevention, Antithrombotic Therapy, and Follow-Up: Jacc State-of-the-Art Review. J Am Coll Cardiol (2020) 75(23):2950-73. doi: 10.1016/ j.jacc.2020.04.031

67. Jadhav S, Ferrell W, Greer IA, Petrie JR, Cobbe SM, Sattar N. Effects of Metformin on Microvascular Function and Exercise Tolerance in Women With Angina and Normal Coronary Arteries: A Randomized, Double-Blind, Placebo-Controlled Study. J Am Coll Cardiol (2006) 48(5):956-63. doi: 10.1016/j.jacc.2006.04.088

68. Ackermann M, Verleden SE, Kuehnel M, Haverich A, Welte T, Laenger F, et al Pulmonary Vascular Endothelialitis, Thrombosis, and Angiogenesis in Covid-19. New Engl J Med (2020) 383(2):120-8. doi: 10.1056/NEJMoa2015432

69. Rangarajan S, Bone NB, Zmijewska AA, Jiang S, Park DW, Bernard K, et al. Metformin Reverses Established Lung Fibrosis in a Bleomycin Model. Nat Med (2018) 24(8):1121-7. doi: 10.1038/s41591-018-0087-6 
70. Yu M, Liu Y, Xu D, Zhang R, Lan L, Xu H. Prediction of the Development of Pulmonary Fibrosis Using Serial Thin-Section CT and Clinical Features in Patients Discharged After Treatment for COVID-19 Pneumonia. Korean J Radiol (2020) 21(6):746-55. doi: 10.3348/kjr.2020.0215

71. Kim J, You YJ. Regulation of Organelle Function by Metformin. IUBMB Life (2017) 69(7):459-69. doi: 10.1002/iub.1633

72. Ilias I, Zabuliene L. Hyperglycemia and the Novel Covid-19 Infection: Possible Pathophysiologic Mechanisms. Med Hypotheses (2020) 139:109699. doi: 10.1016/j.mehy.2020.109699

73. Rangarajan S, Becker EJ, Husain M, Thannickal VJ, Zmijewski JW. Metabolismof Activated Myofibroblasts Is Linked to AMPK Inactivation and Impaired Resolution of Lung Fibrosis. In: . D109. MODULATING the FIBROTIC Response. p. A7876-6.

74. Zhou Z, Tang Y, Jin X, Chen C, Lu Y, Liu L, et al. Metformin Inhibits Advanced Glycation End Products-Induced Inflammatory Response in Murine Macrophages Partly Through AMPK Activation and RAGE/Nf $k b$ Pathway Suppression. J Diabetes Res (2016) 2016:4847812. doi: 10.1155/ 2016/4847812

75. Dominguez Andres A, Feng Y, Campos AR, Yin J, Yang CC, James B, et al. SARS-Cov-2 ORF9c Is a Membrane-Associated Protein That Suppresses Antiviral Responses in Cells. bioRxiv (2020). doi: 10.1101/2020.08.18.256776

76. Yoshimoto FK. The Proteins of Severe Acute Respiratory Syndrome Coronavirus-2 (Sars CoV-2 or n-COV19), the Cause of COVID-19. Protein J (2020) 39(3):198-216. doi: 10.1007/s10930-020-09901-4

77. Azar WS, Njeim R, Fares AH, Azar NS, Azar ST, El Sayed M, et al. Covid-19 and Diabetes Mellitus: How One Pandemic Worsens the Other. Rev Endocr Metab Disord (2020) 21(4):451-63. doi: 10.1007/s11154-020-09573-6

78. Karam BS, Morris RS, Bramante CT, Puskarich M, Zolfaghari EJ, LotfiEmran S, et al. mTOR Inhibition in COVID-19: A Commentary and Review of Efficacy in RNA Viruses. J Med Virol (2020), 1843-6. doi: 10.1002/ jmv. 26728

79. Gordon DE, Jang GM, Bouhaddou M, Xu J, Obernier K, White KM, et al. A SARS-CoV-2 Protein Interaction Map Reveals Targets for Drug Repurposing. Nature (2020) 583(7816):459-68.

80. Zhang J, Dong J, Martin M, He M, Gongol B, Marin TL, et al. AMPActivated Protein Kinase Phosphorylation of Angiotensin-Converting Enzyme 2 in Endothelium Mitigates Pulmonary Hypertension. Am J Respir Crit Care Med (2018) 198(4):509-20. doi: 10.1164/rccm.2017122570OC

81. Malhotra A, Hepokoski M, McCowen KC, ACE2 JYJS. Metformin, and COVID-19. iScience (2020) 23(9):101425. doi: 10.1016/j.isci.2020.101425

82. Li MY, Li L, Zhang Y, Wang XS. Expression of the SARS-CoV-2 Cell Receptor Gene ACE2 in a Wide Variety of Human Tissues. Infect Dis Poverty (2020) 9(1):45. doi: 10.1186/s40249-020-00662-x

83. Xie X, Chen J, Wang X, Zhang F, Liu Y. Age- and Gender-Related Difference of ACE2 Expression in Rat Lung. Life Sci (2006) 78(19):2166-71. doi: 10.1016/j.lfs.2005.09.038

84. Diabetes Prevention Program Research G. Long-Term Safety, Tolerability, and Weight Loss Associated With Metformin in the Diabetes Prevention Program Outcomes Study. Diabetes Care (2012) 35(4):731-7. doi: 10.2337/ dc11-1299

85. Coll AP, Chen M, Taskar P, Rimmington D, Patel S, Tadross JA, et al. GDF15 Mediates the Effects of Metformin on Body Weight and Energy Balance. Nature (2020) 578(7795):444-8. doi: 10.1038/s41586-019-1911-y

86. Singer-Englar T, Barlow G, Mathur R. Obesity, Diabetes, and the Gut Microbiome: An Updated Review. Expert Rev Gastroenterol Hepatol (2019) 13(1):3-15. doi: 10.1080/17474124.2019.1543023

87. Dhar D, Mohanty A. Gut Microbiota and Covid-19- Possible Link and Implications. Virus Res (2020) 285:198018. doi: 10.1016/j.virusres.2020.198018

88. Zuo T, Liu Q, Zhang F, Lui GC, Tso EY, Yeoh YK, et al. Depicting SARSCoV-2 Faecal Viral Activity in Association With Gut Microbiota Composition in Patients With COVID-19. Gut (2021) 70(2):276-84. doi: 10.1136/gutjnl-2020-322294

89. Zhang W, Xu JH, Yu T, Chen QK. Effects of Berberine and Metformin on Intestinal Inflammation and Gut Microbiome Composition in $\mathrm{Db} / \mathrm{Db}$ Mice. BioMed Pharmacother (2019) 118:109131. doi: 10.1016/j.biopha.2019.109131

90. de la Cuesta-Zuluaga J, Mueller NT, Corrales-Agudelo V, Velasquez-Mejia EP, Carmona JA, Abad JM, et al. Metformin Is Associated With Higher
Relative Abundance of Mucin-Degrading Akkermansia Muciniphila and Several Short-Chain Fatty Acid-Producing Microbiota in the Gut. Diabetes Care (2017) 40(1):54-62. doi: 10.2337/dc16-1324

91. Sun L, Xie C, Wang G, Wu Y, Wu Q, Wang X, et al. Gut Microbiota and Intestinal FXR Mediate the Clinical Benefits of Metformin. Nat Med (2018) 24(12):1919-29. doi: 10.1038/s41591-018-0222-4

92. Forslund K, Hildebrand F, Nielsen T, Falony G, Le Chatelier E, Sunagawa S, et al. Disentangling Type 2 Diabetes and Metformin Treatment Signatures in the Human Gut Microbiota. Nature (2015) 528(7581):262-6. doi: 10.1038/ nature15766

93. Klein SL, Flanagan KL. Sex Differences in Immune Responses. Nat Rev Immunol (2016) 16(10):626-38. doi: 10.1038/nri.2016.90

94. Kelly B, Tannahill GM, Murphy MP, O’Neill LA. Metformin Inhibits the Production of Reactive Oxygen Species From NADH : Ubiquinone Oxidoreductase to Limit Induction of Interleukin-1beta (Il-1beta) and Boosts Interleukin-10 (Il-10) in Lipopolysaccharide (LPS)-Activated Macrophages. J Biol Chem (2015) 290(33):20348-59. doi: 10.1074/ jbc.M115.662114

95. Matsiukevich D, Piraino G, Lahni P, Hake PW, Wolfe V, O'Connor M, et al. Metformin Ameliorates Gender-and Age-Dependent Hemodynamic Instability and Myocardial Injury in Murine Hemorrhagic Shock. Biochim Biophys Acta Mol Basis Dis (2017) 1863(10 Pt B):2680-91. doi: 10.1016/ j.bbadis.2017.05.027

96. Malaguarnera R, Sacco A, Morcavallo A, Squatrito S, Migliaccio A, Morrione $A$, et al. Metformin Inhibits Androgen-Induced IGF-IR Up-Regulation in Prostate Cancer Cells by Disrupting Membrane-Initiated Androgen Signaling. Endocrinology (2014) 155(4):1207-21. doi: 10.1210/en.2013-1925

97. Clayton JA, Collins FS. Policy: NIH to Balance Sex in Cell and Animal Studies. Nature (2014) 509(7500):282-3. doi: 10.1038/509282a

98. Razavi AC, Potts KS, Kelly TN, Bazzano LA. Sex, Gut Microbiome, and Cardiovascular Disease Risk. Biol Sex Differ (2019) 10(1):29. doi: 10.1186/ s13293-019-0240-z

99. EY G. Flumamine, A New Synthetic Analgesic and Antiflu Drug. Ph Med Assoc (1950) 26:287-93.

100. Schor S, Einav S. Combating Intracellular Pathogens With Repurposed HostTargeted Drugs. ACS Infect Dis (2018) 4(2):88-92. doi: 10.1021/ acsinfecdis. 7 b00268

101. Singh S, Singh PK, Suhail H, Arumugaswami V, Pellett PE, Giri S, et al. AmpActivated Protein Kinase Restricts Zika Virus Replication in Endothelial Cells by Potentiating Innate Antiviral Responses and Inhibiting Glycolysis. J Immunol (2020) 204(7):1810-24. doi: 10.4049/jimmunol.1901310

102. Cheng F, Ramos da Silva S, Huang IC, Jung JU, Gao SJ. Suppression of Zika Virus Infection and Replication in Endothelial Cells and Astrocytes by PKA Inhibitor PKI 14-22. J Virol (2018) 92(4):e02019-02017. doi: 10.1128/ JVI.02019-17

103. Yu JW, Sun LJ, Zhao YH, Kang P, Yan BZ. The Effect of Metformin on the Efficacy of Antiviral Therapy in Patients With Genotype 1 Chronic Hepatitis C and Insulin Resistance. Int J Infect Dis (2012) 16(6):e436-441. doi: 10.1016/j.ijid.2012.02.004

104. Flory J, Lipska K. Metformin in 2019. JAMA (2019) 321(19):1926-7. doi: 10.1001/jama.2019.3805

105. Henry RR, Frias JP, Walsh B, Skare S, Hemming J, Burns C, et al. Improved Glycemic Control With Minimal Systemic Metformin Exposure: Effects of Metformin Delayed-Release (Metformin DR) Targeting the Lower Bowel Over 16 Weeks in a Randomized Trial in Subjects With Type 2 Diabetes. PloS One (2018) 13(9):e0203946. doi: 10.1371/journal.pone.0203946

106. Kirkman MS, Briscoe VJ, Clark N, Florez H, Haas LB, Halter JB, et al. Diabetes in Older Adults. Diabetes Care (2012) 35(12):2650-64. doi: $10.2337 / \mathrm{dc} 12-1801$

107. Smith FC, Stocker SL, Danta M, Carland JE, Kumar SS, Liu Z, et al. The Safety and Pharmacokinetics of Metformin in Patients With Chronic Liver Disease. Aliment Pharmacol Ther (2020) 51(5):565-75. doi: 10.1111/ apt. 15635

108. FDA. Available at: https://www.fda.gov/drugs/drug-safety-and-availability/ fda-updates-and-press-announcements-ndma-metformin (Accessed July 22, 2020)

109. Alqudah A, McKinley MC, McNally R, Graham U, Watson CJ, Lyons TJ, et al. Risk of Pre-Eclampsia in Women Taking Metformin: A Systematic 
Review and Meta-Analysis. Diabetes Med (2018) 35(2):160-72. doi: 10.1111/ dme. 13523

110. Kalafat E, Sukur YE, Abdi A, Thilaganathan B, Khalil A. Metformin for Prevention of Hypertensive Disorders of Pregnancy in Women With Gestational Diabetes or Obesity: Systematic Review and Meta-Analysis of Randomized Trials. Ultrasound Obstet Gynecol (2018) 52(6):706-14. doi: 10.1002/uog.19084

111. Barbaro M, Hoffman J. The Vaccine Trust Problem [Internet]. New York, NY: National Public Radio (2020). Available at: https://www.nytimes.com/2020/ 07/21/podcasts/the-daily/coronavirus-vaccine.html. July 21 , 2020Podcast.

Conflict of Interest: DV is employed by the company UnitedHealth Group.
The remaining authors declare that the research was conducted in the absence of any commercial or financial relationships that could be construed as a potential conflict of interest.

Copyright (c) 2021 Ibrahim, Lowe, Bramante, Shah, Klatt, Sherwood, Aronne, Puskarich, Tamariz, Palacio, Bomberg, Usher, King, Benson, Vojta, Tignanelli and Ingraham. This is an open-access article distributed under the terms of the Creative Commons Attribution License (CC BY). The use, distribution or reproduction in other forums is permitted, provided the original author(s) and the copyright owner(s) are credited and that the original publication in this journal is cited, in accordance with accepted academic practice. No use, distribution or reproduction is permitted which does not comply with these terms. 